\title{
"Impact of ICT for the 21st Century: A Change Driving Tools for Tertiary Education in Nigeria"
}

\author{
Muhammad Muhammad Suleiman, Tarandeep Kaur, Muhammad Kuliya, Abdulkadir Sarki Aliyu
}

\begin{abstract}
ICTs on their own do not create transformation since they are only facilitators of change, innovation, and creativity. ICT has become an ordinary substance in all measures of a lifetime. Over the past years, the utilization of ICT has an essential level transformed the practices and processes of a wide range of accomplishments in the businesses and organizations. Besides instruction, ICT has instigated to have an understanding nevertheless, the usage of ICT in training fits more learners cantered settings and as often as possible this makes a couple of weights teachers and learners. Regardless, with the global moving fast into innovative multimedia and data developed, the activity of ICT in instruction is ending up being progressively huge and this hugeness will endure to create and make in the Twenty-First Century. This article features several impacts of ICT on existing tertiary education in Nigeria and examines the probable future advances. Text fights the activity of ICT is changing learning and teaching and hopes to research how this will influence the mode wherein tasks will be presented and passed on in the colleges and other tertiary institutions of learning of what might be on the horizon.

Keywords: Classroom; Collaborative Learning Environment; Teaching; 21st Century; Distance Education
\end{abstract}

\section{INTRODUCTION}

Education is among the utmost significant requirements for the prosperity for an individual and public. Along these lines, education is an amazing tool of political, social, and fiscal advancement, deprived of which neither a person nor a public can achieve proficient development. Various authors have characterized ICT.

Oliver \& Chapman, Owolabi et al., (2013) also considered it as the innovation, which supports actions connecting the creation, manipulation, storage and transmission of information (principally computing, electronic and electronic communication) together with their related method management and applications. The concept ICT could be assembled to mean the new media apparatuses applied to information administration conveyance, which incorporates to gather, sort out, recover, spread and safeguard information. It commonly concurs that information is the communication of information, thoughts, qualities, and conventions.

Revised Manuscript Received on June 12, 2020.

* Correspondence Author

Muhammad Muhammad Suleiman*, Department of Computer Application, Lovely Professional, University, Pagwara, India.

Tarandeep Kaur, Department of Computer Application, Lovely Professional, University, Pagwara, India.

Muhammad Kuliya, Department of Computer Application, Lovely Professional, University, Pagwara, India.

Abdulkadir Sarki Aliyu, Department of Computer Application, Lovely Professional, University, Pagwara, India.

(C) The Authors. Published by Blue Eyes Intelligence Engineering and Sciences Publication (BEIESP). This is an open access article under the CC BY-NC-ND license (http://creativecommons.org/licenses/by-nc-nd/4.0/)
Information and communication technology along these lines fills in as the ability to assist social orders with accomplishing more prominent access to information and thoughts. It likewise permits new, quicker and better techniques for instructing and learning forms.ICT is an irreplaceable piece of the modern world. Indeed, society and tradition must be changed in accordance with address the difficulties of the information age. ICT is a control that has changed several parts of individuals' lifestyles. Thinking about such fields as teaching, learning, tourism, transportation, medicine, banking, business, law, architecture and manufacturing the outcome of ICT in the previous a few periods has been huge. The manner in which these fields work currently is immeasurably exclusive in relation to the manner in which they worked previously. By and by, on the off chance that one ganders at the education division, there appears to have little effect on ICT application and far less shift than have been observed in various fields. Nevertheless, numerous individuals have endeavored to explore this absence of action and influence (Soloway \& Pryor, cited in Collis, 2002). Inescapable impact of ICT has achieved a quick innovative, social, political and monetary change, which has prepared to arrange society, composed round ICT. The area of instruction has not been genuine by the entering impact of ICT. Nonetheless, ICT has hugely added to the worth and amount of learning, teaching, and research in usual and distance education colleges. ICT improvements teaching and learning over its dynamic intelligent and connecting with content and gives genuine chances to individualization of studies.

Kirschner and Weperies, cited in Yusuf et al., (2013) state that ICT can make the school increasingly effective and gainful, by sorting out an assortment of apparatuses to improve and encourage educators' expert exercises. Yusuf and Onasanya (2004) discussed that ICT gives chances to the school to speak with each other through email, chat room Conferencing, mailing list and different communication facilities. The three significant explanations behind ICT in education. They are in any case, proposed that it is an device for tending to difficulties in instructional situations; a change operator; and a focal power in economic seriousness. As an instrument for tending to difficulties in technology and processes of learning has the ability for conveyance, the board, and backing of viable learning and teaching. As a change driving, it is fit for varying the content, techniques and various worth and amount of learning and teaching; in this manner, lessening instructors' outstanding task and guaranteeing constructivist request situated study room, (Honey \& Mandinach, 2003).

Published By:

Blue Eyes Intelligence Engineering

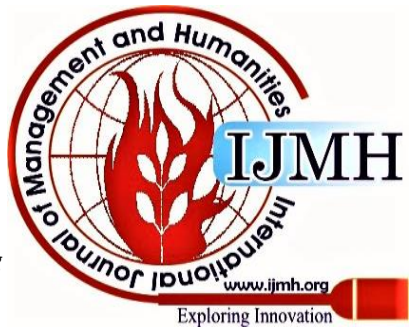


In addition, ICT a focal power in monetary and social moves that have technology abilities basic to the future work of the present learners. Thierer, Yusuf et. al., (2013) stated the role of technology in learning and teaching is quickly getting one of the most significant and broadly talked about issues in

contemporary education approach. Specialists in the fields of education have concurred that, if ICT is appropriately utilized, it holds an extraordinary guarantee to improve teaching and learning notwithstanding forming workforce openings. Along these lines, this research set out to fundamentally evaluate the job of ICT as a change driving instruments for tertiary institutions in Nigeria. Most learners find ICT tools highly appropriate in that they are motivated to do assignments; teachers see that ICT empowers learners with special needs or difficulties. It also helps to reduce the social differences among learners as they work in groups to accomplish a specific undertaking. Equally, learners accept obligations when using ICT to carry out their activities via computerized portfolios or undertakings. In addition, the research has shown that ICT affects educators and methods of teaching significantly. By the righteousness of government Interventions and preparing workshops sorted out right now, devices stimulate educators.

\section{REVIEW OF RELATED LITERATURES}

Numerous specialists and researchers have done famous effort in the field of ICT in Tertiary Education. The review of restricted related researches on Evaluating the Impact of ICT for the twenty-first Century: As Modification Driving Tools for Tertiary Institutions in Nigeria may identify the key trends and gaps in these areas. Many studies have documented either the Evaluating the Impact of ICT for the 21st Century: A Change Driving Tools for Tertiary Education in Nigeria or Information and Communication Technology for Enhancement of Education Development in Northern Nigeria. One of the earliest studies by, Anyasi, et al., cited in State \& Rasheed, 2014) examines the significance of information and communication technology for sustainable development. The author utilized both primary and secondary data to achieve relevant data from the respondents. Specially, structural questionnaire was employed to elicit information from the respondents. The findings reveal that information and communication technology is a necessary tool to achieve sustainable development in Nigeria.

A more recent study by Sukanta, cited in State \& Rasheed (2014) examines the role of ICT in tertiary institutions for the twenty-first century. Study looks into the possible areas where ICT has affected positively vis-a-vis the higher education, research and teaching. The study revered that ICT that lends itself to more learners-centred learning situations. In contrast, Ogunwale et al., cited in State \& Rasheed (2014) conducted a study to find out the degree of perception, acquisition and utilization of wonders of ICT in Irewolede LGA in Ikire Osun Sate. Simple random sampling procedure was used to select fifty teachers as sample for the study. The authors also employed questionnaire as a datagathering instrument. The finding from the study reveals that ICT were grossly inadequate in all the secondary schools selected.
According to the United Nations Educational Science and Cultural Organization (UNESCO), ICT includes 'all types of technology used to produce, store, distribute, transfer and exchange information through means such as telephones, satellites, computers and the Internet, as well as equipment and services related to these technologies, these as video conferencing, online banking, electronic commerce. Yusuf, cited in State \& Rasheed (2014) sees information and communication technology as an automated technology utilized for accessing, gathering, processing, presentation, and dissemination information. Similarly, Sukanta cited in State \& Rasheed (2014) described ICT as the diverse collection of technological equipment and assets that used for the purpose of communication.

However, the various ICT facilities available in colleges of education according to Ofodu, cited in Toyo (2017) include computers, overhead projectors, internet, fax machines, CD-ROMS, electronic notice boards, slides, digital multimedia, video/VCD machine, DVD players and so on.

1) Computer: A device manipulates data or information. It has the ability to hold, recover and process such data. One can utilize a computer for typesetting, browse the internet and send an email. It can also be used to prepare assignments, accounting, handle spreadsheets, database management, games, presentations and more.

2) Overhead Projectors: A projector is a variation of straightforwardness projector that used to show pictures to observers. The projector empowers a simple minimal effort intelligent circumstance for instructors. Training assets can be pre-imprinted on plastic sheets, whereupon the instructor can legitimately form utilizing a non-perpetual, launderable shading-checking pen. This spares time since the straightforwardness can be preprinted and utilized bluntly, instead of having materials formed physically before each class. The projector is commonly put at a happy with composing stature for the teacher and permits the teacher to confront the class, encouraging better messages between the students and educators. The extending highlights of the projector permit the teacher to write in an agreeable little substance in a characteristic composing position as opposed to writing in an excessively huge substance on a marker board and having to continually hold his arm out in midair to make on the marker board (Wikipedia, cited in Toyo, 2017).

3) Compact Disc: CD-ROMs are popularly utilized to distribute computer programs, including video, multimedia applications and games though any data can be stored (up to the capacity furthest reaches of a disk). Some CDs hold both PCs data and audio with the latter capable of being played on a CD player, while data, (for example, application or digital video) is only usable on a workstation (Wikipedia, in Toyo, 2017).

4) Digital Cameras: A camera that records images on an e-image sensor and takes video or photographs. Many of today's cameras are digital cameras that are integrated into many devices ranging from cell phones that PDAs to cars.

Published By:

Blue Eyes Intelligence Engineering

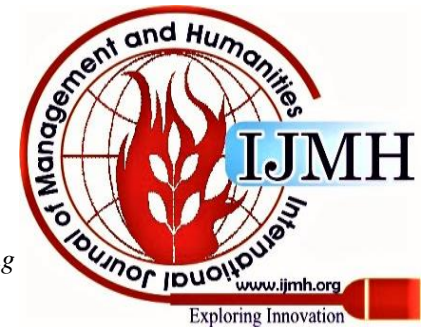


5) Photocopiers: A copier or photocopier is a machine which makes paper duplicates of documents and other photographs quickly and cost-effectively. Most modern copiers use xerography, a heat-using dry process, a technology known as. (Copiers may also use other tools such as inkjet but xerography is popular in the workplace for copying.

The United States of America (USA) has an ICT sector, which is well grown. She is the world's leading exporter of ICT goods and services, adding more than USD 122 billion to US GDP between 2011 and 2013 today.

\section{CONCEPTUAL FRAMEWORK OF ICT COLLABORATION IN TERTIARY EDUCATION}

Wang proposed a conventional model of ICT collaboration having three segments: pedagogy method, technology and social collaboration (Wang, cited in Chowdhury, 2018). These parts as in Figure 1 found in any imparting setting and the sound structure of these segments ought to guarantee a successful ICT collaboration.

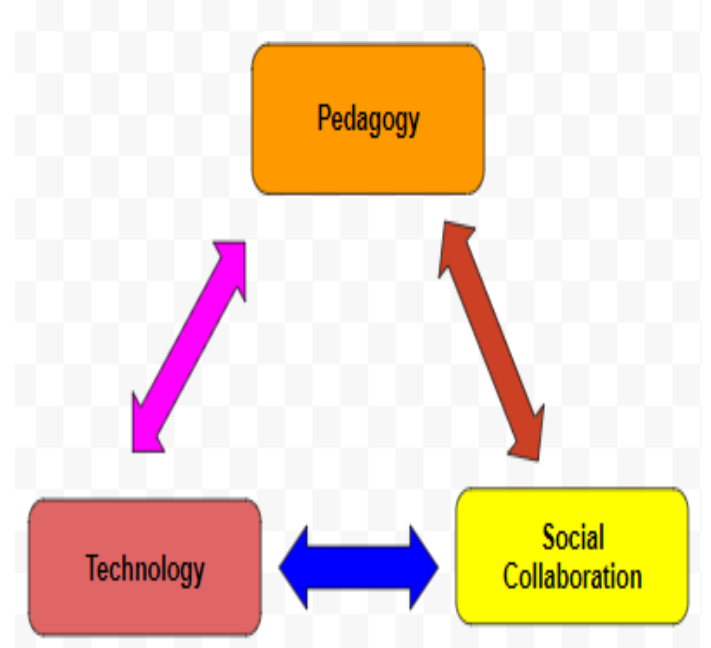

Figure 1: Basic segments of the universal model (Wang, cited in Chowdhury, 2018).

Every one of these parts together structures a constructivist-studies condition. The segments can be available in a conventional lecture room circumstance and it would at present be lined up with constructivist studies. All these three segments have a few qualities and if the attributes are available in a lecture room circumstance, it very well may be said that the segment is available and the combination of ICT has been powerful.

\subsection{Pedagogy:}

It is largely indicated to like the procedures, systems or approaches that educators apply to encourage studies in an instructive setting (Wang, cited in Chowdhury, 2018). A constructivist pedagogical plan is planned by the requirements of the students and platforms them during the learners to accomplish learning targets through the improvement of knowledge dependent on their related experiences (Kirschner, et. al., cited in Chowdhury, 2018). imparting. The constructivist pedagogical plan empowers

\subsection{Technological:}

The technological segment assumes an imperative job in ICT coordinated learning conditions. Accessibility and simple access to advanced gadgets, just as the web, are the pre-imperatives for a successful technology situated learning condition (Salmon, cited in Chowdhury, 2018). Equally, the accessibility of technological fortifications explores the sound plan of pedagogy and social collaboration (Mandell et. al., cited in Chowdhury, 2018).

\subsection{Collaboration:}

Learning is a collective process wherein students overall build knowledge through negotiation, sharing, and altering the data in a gathering (Gunawardena, et. al, cited in Chowdhury, 2018). Social Collaboration incorporates cooperation between student-teacher and student-student. To advance social collaboration the accompanying determinations should be consolidated:

- Workshop hall for online conversations is another determination for guaranteeing social collaboration.

- $\quad \mathrm{A} \mathrm{Q} / \mathrm{A}$ discussion should be organize, in which the students could cooperate with among themselves and the instructor. Collaborations might be through posting general task, answers or remarks with respect to the course plan, assignments or the appraisal. What's more, this discussion may give a stage to the instructor to decide the students' issues and concerns.

- $\quad$ Teamwork should be presented for upgrading social collaboration, in which team individuals could share data, talk about works and questions.

\subsection{Integration of Stakeholders Using ICT in Tertiary Education}

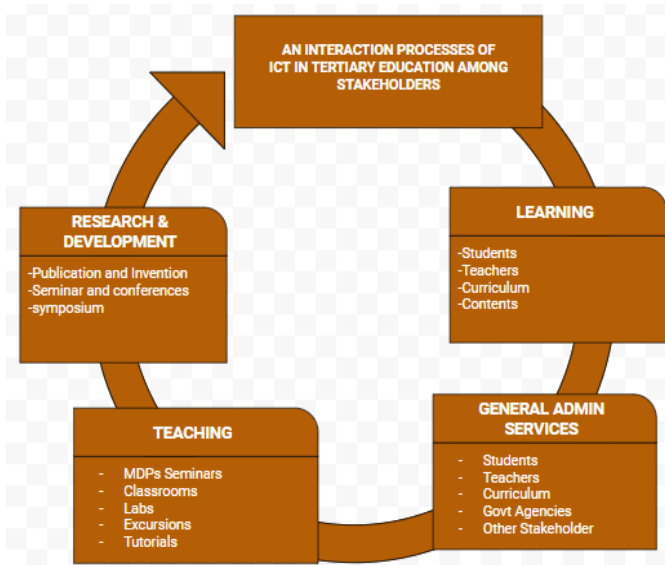

Figure. 2: Integration of Stakeholders Using ICT in Tertiary Education

\section{IMPACTS OF ICT IN TERTIARY EDUCATION}

The utilization of ICT in instruction presents a one of a kind chance to fathom a huge number of difficulties rapidly just as at a low rate. Here is a review of the impacts of an ICT;

a) Motivating Element - Web technology can go about as an inspiring apparatus for some learners.

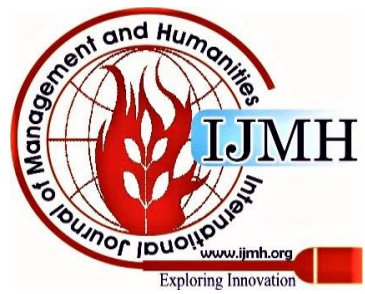


Youngsters are extremely enraptured by innovation. Instructors must gain by this premium energy and eagerness about the net to improve learning. For effectively energetic learners, the web furnishes them with extra learning exercises not promptly accessible in the class.

b) Collaborative Learning Environment - Web encourages co-usable learning, supports discourse and makes an additionally captivating study hall. For instance, a LISTER $\mathrm{V}$ for our group will permit learners to engage in class conversations through messages in a way unrealistic inside four dividers of the study rooms.

c) Fast Message Delivery - Internet advances quick correspondence across land boundaries. Learners can join collective undertakings that include learners from various nations, states or landmasses.

d) Acquiring Different Composing Skills-When learners need to share their work on the web, they need to acquire hypertext skills. Both skills help the learner participate in non-successive compositions

e) Discovering Research Resources - investigate, apart from communication, what brings multiple individuals to the internet. The college library may offer numerous webbased assets.

\subsection{ICT Permits Customized Learning and Organization must follow this Pattern}

ICT depends on individual access, individual PCs and cell phones, so forth just as the new pattern for personalization of the website. This infers the necessities and the skills of learners are very extraordinary, and since ICT permits coordinated learning, progressively personized studies may establish the next pattern of colleges. The better accomplishment of learners is simpler to acquire since the studies is adapted. Nevertheless, this suggests a tremendous modification in the configuration, in the organization of the classes and in the skills and accessibility of instructors. It may clarify the distinctions saw in the effect of ICT towards exhibition of learners. Any place the presentation of IT is concern to personized service for learners, accomplishment increments.

\subsection{Tertiary Institutions serves as an Educational Organization}

Hargreaves and Meighan cited in in Ben Youssef and Dahmani, 2008) contend the possible effect of the usage of ICT in colleges will not be recognizable lacking hierarchical variations at the degree of the entire framework. Colleges must go about as a learning setting. It suggests much organizations between all the on-screen characters. It is the establishment is then creating aggregate learning by varying its guidelines and schedules. Nevertheless, the fundamental change is that advancement turns into the core of the education procedure. Learners and Instructors are investigating the additional opportunities given by these advances and developing capacities concerning studies by using ICT. Structure skills concerning ICT utilization in education turns into an unfair component among colleges. The mentalities toward time, spot, educational plan and other associated qualities of the framework on fundamental stages are evolving.

\subsection{The Results of Tertiary Institutions are Evolving}

The effect of IT on the education procedure is by all accounts more significant and requires more than looking just too educational plans. Improved learner results are watched, concerning inspiration, getting a charge out of confidence; learning; ICT abilities; subject information; communitarian aptitudes; information handling abilities; meta-psychological abilities, and so on. In European tertiary education foundations, while instructors and learners appear to utilize the new accessible advances increasingly more seriously, authoritative structures are evolving gradually. The absence of a system with respect to authoritative change, as a few examinations have appeared, prompts a powerless effect of the utilization of ICT on learner's progress.

\section{TRAINING FLEXIBILITY THROUGH ICT}

ICT is seen to be misuse the dynamicability of studies. The musicality of training, the distribution of time and the accessibility of instructors can permit a better explanation among private life profession life (learning) just as well allotment of time among the different users. This permits better learner ability in financial terms of benefits and accomplishment. There is likewise the nature of the preparation. The instruction provision, the accessibility of assets and the assortment of learning networks may modification following the presentation of the ICT. It would make it workable for learners to obtain e-learning and to create them in the work advertise (OECD, cited in Ben Youssef \& Dahmani, 2008). Some go similarly as guaranteeing that the utilization of creative models of instruction allowed by the presentation of ICT would make it feasible for the learners to "bring out teamwork, to share skill and to reduction individualism in order to support the certified capital" (Lundin and Magnusson, cited in Ben Youssef \& Dahmani, 2008).

\subsection{ICT and Teaching}

Educationists have occupied to the utilization of PCs in instruction considerably more promptly than they received before various media. This is because the quality of PCs is their capacity to control words and images - which is at the core of the educationist undertaking. There is a pattern to present web-based learning or e-learning both in courses that instructed traditional and online learning. Online education and e-Learning are not really something very similar and can have totally varied cost structures. In the case of eLearning improves quality or reduce cost relies upon specific conditions. ICTs by and large and e-learning, specifically, have decreased the obstructions to the instruction to the tertiary institutions.

\subsection{ICT and Raising Standards}

The recent investigation additionally focuses on PC technologies as a noteworthy contributory factor in the increase in expectations of accomplishment in colleges.

Published By:

Blue Eyes Intelligence Engineering

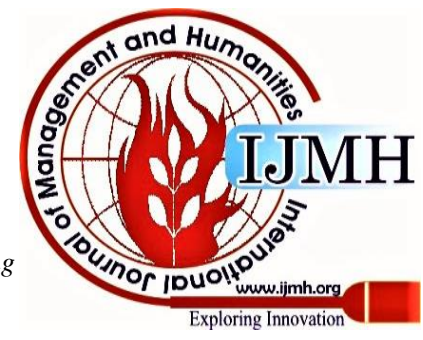


$\checkmark \quad$ Colleges decided by the examiners to have awesome IT assets achieved desired outcomes over ICT-poor schools.

$\checkmark$ Socio-monetary conditions and earlier execution of students were not seen as basic.

$\checkmark$ Largely, better outcomes in Mathematics, English, and Science than persons with deprived ICT assets.

$\checkmark$ Schools that utilized ICT inside a subject would, in general, have preferable accomplishment in that subject over different schools.

The scope of findings shows the capability of PC technology to help enhancements in parts of education, science and numeracy.

$\checkmark$ Better knowledge management skills and increased ability to peruse, decode and draw charts Enhanced comprehension of mathematics (especially critical thinking) and science (especially recreation).

$\checkmark$ Enhanced writing skills — language structure, introduction, pronunciation, understanding of words and work ability.

$\checkmark$ Age improvements in psychological figures and enhanced numbers of skills, for example, number usage

\section{THE UTILIZATION OF ICTS TOOLS IMPROVES THE VALUE OF EDUCATION}

ICTs will improve the quality of teaching in a few different ways: by extending pupils, by promoting motivation and dedication, by facilitating the acquisition of basic skills, and by enhancing the preparation of educators. ICTs are similarly evolutionary instruments that can elevate the step to a student-focused state when used properly.

i) Encouraging learning: ICTs tools such as TV, videos and PC programs that consolidate content, sound, and vivid, moving pictures can be utilized to give testing and legitimate substance that will connect with the learner in the learning procedure. Furthermore, intuitive radio uses audio signals, songs, sounds, comedic creations and other entertainment shows to compel the learners to turn in and become acquainted with the exercises being transmitted. More than any other form of ICT, integrated internetavailable PCs can extend student motivation by consolidating the media resources and expertise of various ICTs with the ability to communicate with genuine individuals and engage in real opportunities.

ii) Enabling the Attainment of background Knowledge: ICTs can be enabled to communicate basic skills and thoughts that constitute the development of higher-request figuring skills and creativity through drilling and practice. For example, instructive TV projects at Sesame Street use reiteration and help to display the letters in order, numbers, hues, shapes, and other simple ideas. Most early use of PCs was for PC-based learning (additionally known as PC-based guidance), which centered on the superiority of skills and substance through reiteration and help

iii) Improving Instructors Preparation: Utilize ICTs to increase access of education stakeholders and collaboration.

\section{INSTANCES OF ICT-BASED UNDERTAKINGS}

What sort of class activities fit to the utilization of ICT? Coming up next is a short manual for the absolute most basic employments of ICT in classroom interactions.

a) Discovery: Learners can use ICT to discover data and increase new knowledge using a few different techniques. They can discover material on the net, or use, for example, Microsoft Encarta, an ICT-based reference book. We can discover data by removing it from a record organized by the teacher, and setting it to be accessible via ICT, such as archives created using Microsoft PowerPoint or Microsoft Word. They can discover information by talking to people elsewhere using email, such as learners in an alternative school or even in an alternative country.

b) Processing knowledge: Learners may use ICT as a portion of an innovative process in which they need to think even more carefully on the data they may have on a specific subject. They may need to make calculations (e.g. using Microsoft Spreadsheet) or test the spelling and arrangement of sentences in a bit of composition (may use Microsoft Word document), or may allow a sequence of occasions to be rearranged (e.g. by re-requesting a PowerPoint sequence).

c) Sharing information: Learner may use ICT to bring their effort into an extremely proficient setup. They will make archives and slide presentations to show what they've learned, and then deliver it to various learners; with their mentor via email to individuals around the world.

7.1 Learn about Internet and Computers: Studies about PCs and the net centers around creating mechanical education. It ordinarily incorporates:

i) Fundamental concepts, thoughts, and operations necessary

ii) Mouse, Cursor and Keyboard use.

iii) Use of productivity methods, such as word document management, database, spreadsheets, and system design.

iv) Basic abilities in utilizing programming and writing applications, for example, Logo or Hyper Studio

$v$ Evolving attention to the public effect of technological change.

vi) Use of investigation and collaboration gears such as social networking sites, e-mail and other search engines.

7.2 Learning with Internet and PCs: Technology learner means reflecting on how creativity will be the closing form of training over the educational programme. This encompasses:

i) Introduction, display and control of information using instruments of efficiency.

ii) Specific application styles such as interactive games, drill and practice, reenactments, training simulations, virtual learning facilities, impressions and visual portrayals of complex concepts, melodic synthesis, and master structures are used in educational programs.

iii) Use of web or CD-ROM information and materials, such as electronic diaries, reference books, intuitive maps and chart books and various guides. 
iv) Technical skills are required for learning with advancement to be conceivable, indicating a two-pronged process in which learners learn about earlier developments they can actually use to obtain them.

\section{PCS AND THE INTERNET UTILIZED IN ELECTRONIC BASED-EDUCATION}

Numerous colleges' offering virtual education programs have begun to use the net to advance their program's span and worth.

\subsection{The Contemporary Position of ICT in Nigerian Education}

Right now, a PC is never again a particular tools utilized uniquely by researchers yet an instrument currently been reached out to education, banking, trade, industry, administration, organization wellbeing segment to make reference to a couple. Seweje, Owolabi, et al., (2013) takes note that Nigeria as a creating country is being more grounded continuously however one significant file of solidarity is the nature of education gave her populace. Today, in most created nations, about each part of human life including instruction is ICT driven. The instruction division in Nigeria despite everything lingers behind right now technology. In any case, the Teachers Registration Council of Nigeria (TRCN) is diverting deliberate endeavours towards this course, National in schools of education has become a modus vivendi for present-day scholastics and learners such a great amount of National Universities Commission (NUC) and the Commission for Colleges of Education (NCCE), (Aturamu, Owolabi, Oyewole, \& Oke, 2013).

In any case, the utilization of ICTs inside the scholarly world particularly so that around is an inseparable connection among ICTs and educational procedures inside tertiary institutions establishments in the country. According to Edewor et al, cited in Toyo (2017), a more intensive glance at the current usage and advantages of ICT instruments in tertiary institutions in Nigeria uncovers the accompanying:

1) PCs and PowerPoint: Higher Institutions in the country across a variety been Computer use supported, including laptops and desktops. Academics and students now use those ICT tools as a way to type, process and store their work for later use. Before the advent of mobile devices such as iPhones, iPods, iPads, and tablets, academia in the 20th century relied heavily on laptops and desktops to produce, convert, and store data.. These tools therefore, enhance Teaching and research.

2) Electronic Mail: Numerous learners and lecturers presently depended on electronic mails to withstand collaboration and advance communication among them. Electronic messages have gotten so helpful to advanced education that it is nearly an abomination not to have one as a teacher or learner.

3) Electronics Peer Review: Peer reviewing is actually digitized, becoming a significant tool or practice that improves the quality of research and academic works. For example, junior researchers will electronically submit draft copies of their works to the email addresses of (their) senior colleagues / experienced researchers for review, while the latter can access those works on their computers or mobile phones, read and review the work to be sent back in the same way, electronically. This method saves both parties paper use, is cost-effective, timely and fast. This process has allowed the internet to take place and provides global connectivity for such interactions.

4) Cooperative Research: The borderless and distance-less net situation has helped to empower collaborative research among and between researchers / academics living and working in far-flung continents. Collaborative research work nowadays is made possible between African scholars and scholars living outside the continent. In the same way, academics conduct transnational partnerships across the continent, and within the African continent, involving nationals of various countries. This brings to bear on the result of these works robustness, freshness, plurality of views, viewpoints and perspectives. The international intelligentsia will also, through these partnerships, pay more attention to research works coming from the continent and make use of these resources to further expand the scope of the global information pool.

5) Digitalization of College Procedures: A measure of the increasing for a green economy, colleges in the country regardless is obligatory to engage digitalization as a universal greatest practice. Currently, admission and application into tertiary Country institutions are conducted through online methods, including payments, registration and enrollment, confirmation of acceptance and publication of stakeholder information. Similarly, e-communication platforms slowly replace face-to - face communication processes, which add speed, ease and timesaving benefits. Digital papers often replace physical papers, which take up space when disposed of and generate environmental eyesore. Additionally, e-libraries are slowly giving way to the introduction of physical libraries. Moreover, in this respect, higher education is not left behind in Nigeria.

6) 6) Websites: Maximum, colleges in the country have several websites containing their corporate information, as well as other data. Higher institutions are able to communicate with their students and staff through this forum, and address the needs of other stakeholders. In addition, blogs have become marketing vehicles for higher institutions through remaining channels of contact to clarify the respective institutions' programs and activities. Higher education in the country is now thriving across postsecondary institutions' websites, which constantly invest in their websites to achieve their various benefits or goals.

7) Conferencing: Colleges work slowly on receiving electronic meeting paybacks. Through this process, resources for distance learning can be developed or maintained, and wide-ranging research teams can meet to discuss or exchange findings that could improve the quality of the research results. E-interview is another common feature of this use. For example, some universities, such as Covenant University, have started using online interviews to engage academics of Nigerian and foreign origin who live outside the country 's shores.

Published By:

Blue Eyes Intelligence Engineering

\& Sciences Publication

(C) Copyright: All rights reserved.

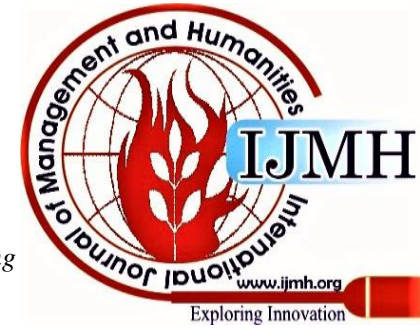


8) Electronic Learning Gears (e.g. web 2.0): Imhonopi and Urim cited in Toyo, (2017), a range of elearning platforms are increasingly becoming the standard in and for higher education in Nigeria. Those include online resources , tools, apps, and platforms that allow language teaching and learning both inside and outside of college. They include the internet, forums, e-groups, SMSs, socializing sites, e-dictionaries, encyclopedia, audio and video clip PowerPoint presentations, webcasting, and audiovideo content. These include teleconferencing (text-based, video and audio conferencing), virtual television, digital satellite TV, audio graphics, online chats, newsletters, etc.

9) Smartwatch is a modernized, useful wristwatch which improves past timekeeping. Although early copies will perform fundamental tasks, such as google maps, readings, calculation, and game play, today's smartwatches are effectively wearable PCs. Numerous programs run lightweight, using a lightweight working system. Furthermore, the need for effective use of ICT facilities most especially among Nigerian tertiary institutions is highly fundamental. However, it could be a fundamental one only when authorities of these institutions realized that all the ICT facilities found in their institutions are categorized into computers, storage media and telecommunication (Mondal \& Mete, 2012). When they realized that the computer in their offices performed processing operations on data, they process store and retrieve information as well assorted data, and that storage media such as magnetic disks and tapes, CD-ROM and diskettes are used to provide additional storage media for information.

\section{LIMITATIONS TO THE EFFECTIVE IMPLEMENTATION AND UTILIZATION OF ICT FACILITIES IN TERTIARY OF EDUCATION} adoption and utilization in some higher institutions of learning especially in colleges of education within the last couple of years, major constraints still obstruct the actual adoption and operation of these facilities in education colleges even in Delta State. There have been some studies on the influences militating the implementation and incorporation of ICTs in tertiary institutions (Oladokun, 2012). One of such studies include the study of Edewor, Imhonopi and Urim (2014) who highlighted the following as the constraints to the effective adoption and utilization of ICT in higher institutions of learning:

i) Inadequate Financial Support has stayed a tall test for vigorous and successful colleges in country. Conceded that financing college in any economy, regardless of whether created or creating, is costly, in the country, tertiary education has gotten a few thumps from the foundation as the administration has bombed in its promise to put vigorously in the subsector. While the administration claims it experiences a lack of assets, it is astonishing when one deliberates the cost of administration in country which whenever restrained could permitted assets for interest in teaching.

ii) The spotty power asset is moreover additional test that controls tries to standard ICTs for advanced education
Although, significant progress has been observed in ICT

improvement in the country. In Nigeria at present delivers under 4,000 megawatts of power, which is extraordinarily inadequate to address the issues of the nation over all areas, including the training part. Since one type of vitality or different forces, ICTs straightforwardly as well as by implication, rectifying the imperfections/challenges intrinsic in the force segment and recovering the segment to address the issues of a cutting edge state will give the required lift to ICT reconciliation in tertiary education in the country.

iii) Absence of framework is added test to colleges in the country. There are rises of proof demonstrating that current higher establishments in the nation come up short on the essential physical classes, educating and learning apparatuses, and present-day ICTs that could assist them with directing instructing, learning and research forms in a forgiving nature.

iv) Official defilement and different indecencies inside the administration plane have likewise made a genuine conflation of powers to weaken tertiary education in Nigeria. The ramifications of the few money-related misconducts submitted by selected and named government authorities to leave the management prostrates to meet its commitments to tertiary education.

v) Nonattendance of political assurance and prioritization of hypotheses by the governing body are various issues that disappoint ICT and tertiary institutions improvement in the country.

vi) Poor reserve funds in ICTs for innovative instruction improvement is another deferral in the improvement of the subsector. There is no country that needs to lead others despises or hates innovation. Without innovation apparatuses as gave by ICTs, tertiary institutions will be enormously smothered with the absence of streamlining numerous advantages

vii) Unavailability of related application for instruction through ICT offices are difficult undertaking deprived of cutting-edge hardware and valuable materials. According to Salomon, in cited in Toyo (2017) there are clear signs from numerous nations that the supply of pertinent and proper programs is a significant impediment discouraging more extensive utilization of the PC technologies.

\section{CONCLUSION}

The work of ICTs in an instruction are unavoidable and recurring. Rapid advancement in the innovations is demonstrating that the impact of ICT, later on, will develop hugely in education. Eventually, the utilization of ICT will improve the learning encounters of learners. Likewise, it causes them to think autonomously and convey innovatively. It additionally helps learners for building successful professions and lives, in an undeniable technological world. The researcher triedd to assess the impact of technology as a modification driving tools for tertiary institutions in Nigeria. Research showed that technologies have essentially affected towards educational rehearsal in Nigeria, which would develop significantly in the future if the different issues thwarting successful usage of technology as a variation operator for tertiary institutions were appropriately improved.

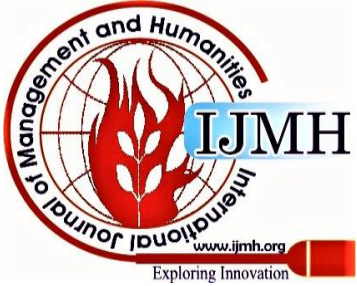




\section{RECOMMENDATIONS}

1) Government and Non-governmental Organization should increase budget allocation to institutions to enable them embark on Information and Communication Technology.

2) Government should make Information and Communication Technology part of National minimum standards for all graduates in Nigeria.

3) Workshop, seminars should be organized regularly to create proper awareness of ICT to students and teachers.

4) Steady electricity supply and telecommunication facilities should be provided in urban and rural areas to facilitate the implementation of ICT.

5) The use of ICT in the educational instructions for all levels of system should be highly encouraged by the government through the supply of computers and other ICT gadgets.

\section{REFERENCES}

1. Ben Youssef, A., \& Dahmani, M. (2008). The Impact of ICT on Student Performance in Higher Education: Direct Effects, Indirect Effects and Organisational Change. RUSC. Universities and Knowledge Society Journal, 5(1) https://doi.org/10.7238/rusc.v5i1.321.

2. Owolabi, T. O., Oyewole, B. K., \& Oke, J. O. (2013). Teacher Education, Information and Communication Technology: Prospects and Challenges of E-Teaching Profession in Nigeria. American Journal of Humanities and Social Sciences, 1(2), 87-91. https://doi.org/10.11634/232907811301314

3. Collis, B. (2002). Information Technologies for Education and Training. In Adelsberger, H., Duffy, T., \& Cunningham, D. (1996). Constructivism: Implications for the design and delivery of instruction, Handbook of research for educational telecommunications and technology (pp. 170-198). New York: MacMillan.

4. Federal Ministry of Communication Technology, Report on Nigeria: Leveraging ICT for National Development, Creating a Digital Economy, February 2013.

5. Jekayinoluwa, J. R and OJO, O.S (2010). Challenges and Prospects of Information and Communication Technology in Teacher Education Curriculum. South West Journal of Teacher Education, Vol. 3(1), Pp.583-597

6. M. J., Oliveira, L. R., \& Blanco, E. (2002). The use of ICT in higher education: Work in progress at the University of Minho [*]. (September 2002), 1-13. Retrieved from http://www.uoc.edu/dt/20137/index.html

7. Ogu, E., \& Oyerinde, O. (2014). ICT and National Security in Developing and Underdeveloped Countries - The Good, The Bad and The Ugly: A Case Study of Nigeria's Cyberspace. 5(4), 5625-5633.

8. Owolabi, T. O., Oyewole, B. K., \& Oke, J. O. (2013). Teacher Education, Information and Communication Technology: Prospects and Challenges of E-Teaching Profession in Nigeria. American Journal of Humanities and Social Sciences, 1(2), 87-91.

9. Ramirez-Romero, J. L., Rodriguez-Rosales, M., \& Salazar-Sorcia, H. (2018). The role of ICT in the evaluation and assessment of English as foreign or as a second language. In Beyond Paper-and-Pencil Tests: Good Assessment Practices for EFL Classes.

10. Ron Oliver, The role of ICT in higher education for the 21st century: ICT as a change agent for education, Edith Cowan University, Perth, Western Australia, r.oliver@ecu.edu.au. Accessed 12:10pm, 11-03-15

11. Sinha, S., \& Lamba, S. (2016). Role of ICT in Higher Education. Anusandhaan - Vigyaan Shodh Patrika, 4(1), 2810-2813. https://doi.org/10.22445/avsp.v4i1.4397

12. State, K., \& Rasheed, I. (2014). Role of ICTs in Enhancing a Sustainable Educational Development in Selected Secondary Schools in Ilorin Metropolis. 5(9), 89-94.

13. Sunday, A. F. (2015). Effective Teaching With ICT in Nigerian Higher Institutions: a Solution To Graduate Employability. Journal of Educational Review, 8(3), 231-239.
14. Toyo, O. D. (2017). Information and Communication Technology ( ICT ) Adoption and the Educational Growth of Colleges of Education in Agbor and Warri , Delta State , Nigeria. International Journal of Education and Evaluation, 3(7), 19-32.

15. UNESCO Institute of Statistics (2014). Information And Communication Technology (ICT) In Education In Asia: A comparative analysis of ICT integration and e-readiness in schools across Asia. Montreal, Canada. Vol. 1(22) http://www.uis.unesco.org.

16. UNESCO Workshop on Using ICT to Develop Literacy, Bangkok, Thailand (2007).

17. Vasslios, M. (2012). ICT in Education for sustainable Development. UNESCO ICT in Education, news letter.

18. Young, J. (2002). The 24-hour professor. The Chronicle of Higher Education, 48(38), 31-33.

19. Yusuf, M., Oluwole, A. F., Loto, A., Adeoye, Y. M., Oluwole, A. F. \& Blessing, L. A. (2013). International Journal of Educational Administration and Policy Studies Appraising the role of information communication technology (ICT) as a change agent for higher education in Nigeria. International Journal of Current Research and Academic Review, 5(4), 177-183.

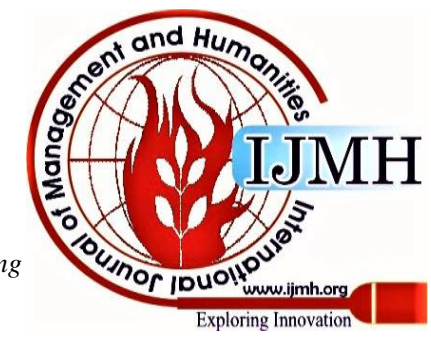

